\title{
Joint Impact of Dimensions of Governance and \\ Economic Freedom on Economic Growth in O.E.C.D. Nations: An Analysis with Controls for Budget Deficits and G8 Status
}

\author{
Richard J. Cebula (Corresponding Author) \\ Department of Economics \\ Armstrong Atlantic State University \\ Savannah, Georgia, U.S.A. \\ E-mail: Richard.Cebula@armstrong.edu
}

\author{
Marcus Ekstrom \\ Department of Economics \\ Armstrong Atlantic State University \\ Savannah, Georgia, U.S.A. \\ E-mail: Cebulari@mail.armstrong.edu
}

\begin{abstract}
This study examines the impact of various forms of economic freedom and various dimensions of governance, as well as a number of economic factors, on economic growth among O.E.C.D. nations. The study period runs from 2004 through 2007. The study adjusts for status as a G8 nation and for budget deficits. Panel least squares estimation finds that the natural log of per capita purchasing-power-parity adjusted real GDP in O.E.C.D. nations is positively impacted by business freedom, monetary freedom, trade freedom, and property rights security. Economic growth is found to be negatively affected by perceived government corruption while being positively impacted by both control of corruption and political stability. Other findings indicate that higher unemployment rates and higher long term nominal interest rates inhibit economic growth, while net export growth enhances economic growth.
\end{abstract}

Keywords: Economic growth, Economic freedom, Governance, G8 status, Budget deficit 


\section{Introduction}

Numerous studies have been conducted to investigate the linkage between economic freedom and economic growth. Most of these studies conclude that there exists a positive impact of various measures of economic freedom on economic growth (Barro, 1997; De Haan \& Siermann, 1998; De Haan \& Sturm, 2000; Heckelman \& Stroup, 2000). Other studies have found that governance influences economic growth (Akcay, 2006; Brito-Bigott, Faria, Rodriguez, \& Sanchez, 2008).

This study focuses on the relationship between economic growth on the one hand and both various dimensions of governance and economic freedom on the other hand in a somewhat different framework than most previous related studies. In particular, in light of the de facto global recession currently being experienced, the O.E.C.D. is working with the world's governments and other organizations to get economies back on the path of economic expansion and stabilization. As a central part of this effort, the O.E.C.D. strongly takes the position that governments must be cautious not to jeopardize economic freedom and/or good governance as they seek ways in which to get their economies healthy again. In other words, nations must continue to support and promote good governance and economic freedom (O.E.C.D., 2009). The concern in this context is that the abandonment of economic freedoms and/or good governance will result over time in diminished economic growth and thus lead to a deeper and longer world economic slowdown.

The purpose of this empirical study is to test the joint hypothesis that governance and economic freedom both influence real economic growth. The latter is measured in this study by natural log of the PPP (purchasing-power-parity)-adjusted per capita real GDP. Given that the O.E.C.D. is expressly concerned over this issue, the framework for the study consists of the nations that comprise the O.E.C.D. The PLS (panel least squares) estimation applies for the four-year period 2004 through 2007. To test the basic model for robustness, two additional estimates are provided in order to account for status as a G8 nation and for the size of each nation's central government budget deficit.

\section{The Initial Framework}

This study focuses on economic growth among the O.E.C.D. member countries for the period 2004-2007. Economic growth is measured as the natural log of per capita real GDP year-to-year over the study period, log RPCY, made comparable across nations by PPP (purchasing power parity) adjustments. In turn, in principle following a number of studies focused upon economic growth (Cebula, 1978, 1995; Barro, 1997), it is hypothesized that economic growth depends not only upon various forms of economic freedom (FREEDOM) and various dimensions of good governance (GOODGOV), but also upon a number of purely economic factors $(\mathrm{ECON})$, such that:

$\log$ RPCYpppj = f(FREEDOMj, GOODGOVj, ECONj)

where: 
$\operatorname{logRPCYpppj}=$ the natural log of the purchasing-power-parity adjusted per capita real GDP in OECD nation $\mathrm{j}$; FREEDOMj refers to values of economic freedom measures in nation $\mathrm{j}$; GOODGOVj refers to values of good (or bad) governance measures in nation $\mathrm{j}$; and $\mathrm{ECONj}$ refers to economic factors in nation $\mathrm{j}$.

There are five forms of economic freedom considered in this study. The first considered here is trade freedom. Trade freedom (TF) reflects the openness of an economy to imports of goods and services from other nations as well as the ability of citizens to interact freely as sellers and buyers in the international marketplace. The second economic freedom considered is business freedom (BF), which reflects the individual's right to freely conduct entrepreneurial activities, e.g., starting and operating a business firm without government interference. The third economic freedom studied here is monetary freedom (MF), which is illustrated by a stable currency and system of market-determined pricing. Citizens need a stable and reliable monetary system (currency) to serve as both a reliable medium of exchange and store of value (wealth). Property rights (PR), which is another form of economic freedom, constitutes a moving force in the quest to accumulate private property in a market-driven environment. Secure property rights provide people the confidence to undertake entrepreneurial activities, to save, and to invest (Goldsmith, 1995; Heckelman, 2000). The fifth economic freedom measure considered here is GSF, government size freedom. The GSF index measures the extent to which the private sector of an economy is free from the burden of excessive government expenditures (which are often justified in terms of public goods provided allegedly more efficiently by the "state" rather than by the market or justified in terms of correcting alleged "market failures"). This dimension of government size is often associated with "crowding out" (Carlson \& Spencer, 1975, Cebula, 1978). The GSF index also reflects the degree to which the private sector is insulated from government tax burdens. Following the related literature to date, it is expected (ceteris paribus) that economic growth is an increasing function of each one of these economic freedom measures:

$\mathrm{f}_{\mathrm{TF}}>0, \mathrm{f}_{\mathrm{BF}}>0, \mathrm{f}_{\mathrm{MF}}>0, \mathrm{f}_{\mathrm{PR}}>0, \mathrm{f}_{\mathrm{GSF}}>0$

There are three dimensions of governance included in this study. They are control of corruption (CORRCONTR), political stability and absence of violence/terrorism (POLSTAB), and perceived government corruption (PERCORR). To begin, it is observed that "corruption" is defined essentially in general terms as the misuse of public power for private gain (Akcay, 2006).

The CORRCONTR dimension of governance is an index measuring the extent to which government limits the exercise of power by non-elected government officials for personal gain, including both petty and grand forms of corruption, as well as control of state powers by private interests. The greater the degree in which corruption is controlled, the greater the incentive to invest and participate in private enterprise, and hence the greater the rate of economic growth, ceteris paribus. The POLSTAB dimension of governance is an index indicating the likelihood that government will not be destabilized by unconstitutional or violent means, including acts of terrorism. The higher the value of this index, the greater the 
likelihood that the private sector investment will occur and that private enterprise will flourish, thereby resulting in greater economic growth, ceteris paribus. Finally, the PERCORR variable is an index reflecting the perception by the private sector that elected government officials are corrupt. This index is a separate measure of corruption, namely, corruption among elected government officials, and the degree to which governments, even democratic ones, continue to be corruptly controlled by same. Clearly, the greater the magnitude of this index, the less the incentive to assume risks of investment by the private sector; hence the slower should be the rate of economic growth, ceteris paribus. Based upon the arguments stated above, the following is to be expected:

$\mathrm{f}_{\text {CORRCONTR }}>0, \mathrm{f}_{\text {POLSTAB }}>0, \mathrm{f}_{\text {PERCORR }}<0$

This analysis initially controls for purely economic determinants of economic growth by adopting three economic variables. These variables take the following forms: LR, the nominal long term interest rate; UR, the percentage unemployment rate of the labor force; and $\triangle \mathrm{NXY}$, growth of net exports, expressed as a percent of GDP (Cebula, 1995; Barro, 1997). Presumably, economic growth is a decreasing function of LR since a higher long term interest rate acts to discourage investment in new plant and equipment as well as new residential construction, ceteris paribus. Similarly, a higher UR implies a slower rate of economic growth because a higher percentage of the labor force is unemployed. Finally, a higher $\triangle \mathrm{NXY}$ implies a greater rate of real domestic production, ceteris paribus. Hence, it follows that:

$\mathrm{f}_{\mathrm{LR}}<0, \mathrm{f}_{\mathrm{UR}}<0, \mathrm{f}_{\Delta \mathrm{NXY}}>0$

Based on the variables identified above, equation (1) is initially rewritten as:

$\log$ RPCYpppj = f(TF, BF, MF, PR, GSF, CORRCONTR, POLSTAB, PERCORR,

LR, UR, $\triangle \mathrm{NXY}$ )

\section{Empirical Results}

Based in turn on (5), the following semi-log model is to be estimated:

$\log$ RPCYpppjt $=a_{0}+a_{1}$ TFjt $+a_{2}$ BFjt $+a_{3}$ MFjt $+a_{4}$ PRjt $+a_{5}$ GSFjt

$+\mathrm{a}_{6}$ CORRCONTRjt $+\mathrm{a}_{7}$ POLSTABjt $+\mathrm{a}_{8}$ PERCORRjt $+\mathrm{a}_{9}$ LRjt $+\mathrm{a}_{10}$ URjt

$+\mathrm{a}_{11} \Delta \mathrm{NXYjt}+\mathrm{u}$

where

$\log$ RPCYpppjt = the natural log of the purchasing-power-parity adjusted real per capita GDP in O.E.C.D. nation j, year t;

$\mathrm{a}_{0}=$ constant;

$\mathrm{TFj}=$ the value the trade freedom index in O.E.C.D. nation $\mathrm{j}$, year $\mathrm{t}$;

$\mathrm{BFj}=$ the value of the business freedom index in O.E.C.D. nation $\mathrm{j}$, year $\mathrm{t}$; 
$\mathrm{MFjt}=$ the value of the monetary freedom index in O.E.C.D. nation $\mathrm{j}$, year $\mathrm{t}$;

$\mathrm{PRjt}=$ the value of the property rights index in O.E.C.D. nation $\mathrm{j}$, year $\mathrm{t}$;

$\mathrm{GSFjt}=$ the value of the freedom from excessive government index in O.E.C.D. nation $\mathrm{j}$, year t;

CORRCONTRjt $=$ the value of the control of corruption index among government officials in O.E.C.D. nation $\mathrm{j}$, year $\mathrm{t}$;

POLSTABjt $=$ the value of the index of political stability in O.E.C.D. nation $j$, year $t$;

PERCORRjt $=$ the value of the index of perceived corruption of elected government officials in O.E.C.D. nation $\mathrm{j}$, year $\mathrm{t}$;

$\mathrm{LRjt}=$ the percentage nominal long run interest rate in O.E.C.D. nation $\mathrm{j}$, year $\mathrm{t}$;

$\mathrm{URjt}=$ the percentage unemployment rate of the civilian labor force in O.E.C.D. nation $\mathrm{j}$, year $\mathrm{t}$;

$\Delta \mathrm{NXYjt}=$ the growth of the ratio of net exports to the GDP in O.E.C.D. nation $\mathrm{j}$, year $\mathrm{t}$;

$\mathrm{u}=$ stochastic error term;

where $\mathrm{t}=2004,2005,2006,2007$ and $\mathrm{j}=1, \ldots 30$.

The data sources for the variables in the analysis are, as follows:

log RPCYpppjt, IMF (2008); freedom indices, TF,BF, MF, PR, GSF, Heritage Foundation (2008); governance indices, CORRCONTR, POLSTAB, PERCORR, World Bank (2009); and explanatory economic variables, LR, UR, and NXY, OECD (2008).

The heteroskedasticity-adjusted PLS (panel least squares) estimate of equation (6) is provided in column (1) of Table 1. In this estimation, the coefficients on all 11 of the explanatory variables exhibit the expected signs, with seven being statistically significant at the five percent level and three being statistically significant at the one percent level.

In particular, the coefficients on the variables TF, BF, MF, PR, CORRCONTR, POLSTAB, and UR are statistically significant at the five percent level, whereas those on PERCORR, LR, and $\triangle \mathrm{NXY}$ are statistically significant at the one percent level. Only the coefficient on the variable GSF fails to be statistically significant at the ten percent level.

The $\mathrm{R}^{2}$ is 0.84 , so that the model explains approximately five-sixths of the variation in the dependent variable. The F-statistic is statistically significant at the one percent level, attesting to the overall strength of the model.

Based on the PLS results in column (1) of Table 1, the economic growth rate (as measured) in OECD nations over the 2004 through 2007 study period is an increasing function of TF, BF, MF, PR, CORRCONTR, POLSTAB, and $\triangle N X Y$, while being a decreasing function of PERCORR, LR and UR. 
Thus, economic growth in these nations over the study period was positively a function of economic freedom, as measured by TF, BF, MR, and PR. Accordingly, economic growth is greater with higher levels of trade freedom, business freedom, monetary freedom, and a more secure system of property rights protection. These findings are consistent with nearly all of the existing literature on the relationship between economic growth and economic freedom (Barro, 1997; De Haan \& Siermann, 1998; De Haan \& Sturm, 2000; Heckelman \& Stroup, 2000).

Economic growth also is found to beneficially impacted by "positive" forms of governance in the forms of control of corruption (CORRCONTR) and political stability (POLSTAB). Not surprisingly, however, the perception of greater corruption of elected government officials acts to retard economic growth. Clearly, the PLS findings summarized in column (1) of Table 1 indicate that in addition to traditionally recognized forms of economic freedom, governance effectiveness vis-à-vis free markets promotes economic growth.

Naturally, fundamentally economic influences play a significant role in economic growth. According to column (1) of Table 1, economic growth in O.E.C.D. nations was negatively impacted both by higher nominal long term interest rates (LR) and higher unemployment rates (UR), while being positively impacted by export growth ( $\triangle \mathrm{NXY})$. These latter findings are compatible with previous research (Cebula, 1995; Barro, 1997).

\section{An Expanded Model}

To test the robustness of the above results, the basic model is expanded in two ways. First, since the G8 nations are all members of the O.E.C.D .and all have higher real per capita income levels, the model is first adjusted to account for G8 status. This is accomplished through the introduction of a dummy variable, G8DUMMY, which assumes a value of 1 for each of the G8 nations and a value of 0 otherwise. Naturally, it is expected that the sign on this binary variable is positive.

Next, in order to reflect the impact of fiscal policy on economic growth, the central government federal budget deficit for each of the O.E.C.D. nations is considered. Variable DEFjt is the ratio of the budget deficit in nation $j$ in year $t$ to the GDP in nation $j$ in year $t$, expressed as a percentage (O.E.C.D., 2008). Following previous research (Carlson \& Spencer, 1975; Cebula, 1995; Barro, 1997), the expected impact of the budget deficit on economic growth is negative, ceteris paribus, due to crowding out.

The estimate of the basic model with the binary variable G8DUMMYincluded is provided in column (2) of Table 1. All 12 of the coefficients shown in estimate (2) exhibit the expected signs; furthermore, seven are statistically significant at the five percent level and four are statistically significant at the one percent level. Once again, the GSF variable, although positive, is not statistically significant at the ten percent level.

Thus, for the variables common to both columns (1) and (2), the results are very similar. In particular, the economic growth rate is again found to be an increasing function of $\mathrm{TF}, \mathrm{BF}$, MF, PR, CORRCONTR, POLSTAB, and $\triangle N X Y$, while being a decreasing function of PERCORR, LR, and UR. Furthermore, the coefficient on the control dummy variable 
G8DUMMY is positive, as expected, and significant at the five percent level. Clearly, the conclusions found for the model shown in estimation (1) of Table 1 are reaffirmed even after controlling for the higher real GDP levels found in the G8 nations.

Finally, the estimate of the basic model with both the binary variable G8DUMMY and the budget deficit variable DEFtj included is provided in column (3) of Table 1. The results for the first 11 variables shown are entirely compatible with those in columns (1) and (2). In addition, the result for the variable G8DUMMY is compatible with its counterpart in column (2). Finally, in column (3), the result for the DEF variable is a negative coefficient that is statistically significant at beyond the six percent level, implying effectively that greater budget deficits reduce real economic growth.

\section{Conclusion}

This panel least squares study of the O.E.C.D. nations finds that economic growth over the 2004-2007 study period was positively a function of economic freedom, as measured by TF, $\mathrm{BF}, \mathrm{MR}$, and PR. Accordingly, economic growth is greater with higher levels of trade freedom, business freedom, monetary freedom, and a more secure system of property rights protection. These findings are consistent in principle with nearly all of the existing literature on the relationship between economic growth and economic freedom (Barro, 1997; De Haan \& Siermann, 1998; De Haan \& Sturm, 2000; Heckelman \& Stroup, 2000).

Economic growth also is found to be enhanced by "positive" dimensions of governance in the forms of control of corruption of non-elected government officials (CORRCONTR) and political stability (POLSTAB). On the other hand, the perception of greater corruption of elected government officials acts to retard economic growth. Clearly, these findings indicate that in addition to traditionally recognized forms of economic freedom, effective governance vis-à-vis free markets promotes economic growth.

Naturally, fundamentally economic influences play a significant role in economic growth. According to Table 1, economic growth in OECD nations was negatively impacted by higher nominal long term interest rates (LR), higher unemployment rates (UR), and larger government budget deficits, while being positively impacted by export growth $(\triangle \mathrm{NXY})$ and status as a G8 nation. These findings are compatible in spirit with previous research (Cebula, 1995; Barro, 1997). 


\section{IIMacrothink}

Table 1. Panel least squares estimates

\begin{tabular}{|c|c|c|c|}
\hline Variables $\backslash$ Estimates & (1) & $(2)$ & (3) \\
\hline Constant & 2.61 & 3.25 & 2.97 \\
\hline TFjt & $\begin{array}{c}0.011 * * \\
(2.48)\end{array}$ & $\begin{array}{c}0.009 * * \\
(2.27)\end{array}$ & $\begin{array}{c}0.009 * * \\
(2.28)\end{array}$ \\
\hline BFjt & $\begin{array}{c}0.007 * * \\
(2.34)\end{array}$ & $\begin{array}{c}0.006^{* *} \\
(2.09)\end{array}$ & $\begin{array}{c}0.006^{* *} \\
(2.20)\end{array}$ \\
\hline MFjt & $\begin{array}{c}0.026 * * \\
(2.54)\end{array}$ & $\begin{array}{c}0.022 * * \\
(2.21)\end{array}$ & $\begin{array}{c}0.0238 * * \\
(2.23)\end{array}$ \\
\hline PRjt & $\begin{array}{c}0.012 * * \\
(2.28)\end{array}$ & $\begin{array}{l}0.01 * * \\
(2.15)\end{array}$ & $\begin{array}{c}0.01 * * \\
(1.99)\end{array}$ \\
\hline GSFjt & $\begin{array}{l}0.002 \\
(1.20)\end{array}$ & $\begin{array}{l}0.002 \\
(1.14)\end{array}$ & $\begin{array}{c}0.0018 \\
(1.38)\end{array}$ \\
\hline CORRCONTRjt & $\begin{array}{c}0.467 * * \\
(2.13)\end{array}$ & $\begin{array}{c}0.505^{* *} \\
(2.31)\end{array}$ & $\begin{array}{c}0.473 * * \\
(2.12)\end{array}$ \\
\hline POLSTABjt & $\begin{array}{c}0.167 * * \\
(2.08)\end{array}$ & $\begin{array}{c}0.247 * * * \\
(2.79)\end{array}$ & $\begin{array}{c}0.279 * * * \\
(3.01)\end{array}$ \\
\hline PERCORRjt & $\begin{array}{c}-0.25 * * * \\
(-2.63)\end{array}$ & $\begin{array}{c}-0.27 * * * \\
(-2.78)\end{array}$ & $\begin{array}{c}-0.25 * * * \\
(-2.59)\end{array}$ \\
\hline LRjt & $\begin{array}{c}-0.11 * * * \\
(-3.14)\end{array}$ & $\begin{array}{c}-0.107 * * * \\
(-3.24)\end{array}$ & $\begin{array}{c}-0.105 * * * \\
(-3.08)\end{array}$ \\
\hline URjt & $\begin{array}{c}-0.031 * * \\
(-2.47)\end{array}$ & $\begin{array}{c}-0.035^{* *} \\
(-2.48)\end{array}$ & $\begin{array}{c}-0.03 * * \\
(-2.09)\end{array}$ \\
\hline$\Delta \mathrm{NXYjt}$ & $\begin{array}{c}0.545^{* * *} * \\
(2.88)\end{array}$ & $\begin{array}{c}0.491 * * * \\
(2.59)\end{array}$ & $\begin{array}{c}0.436^{* *} \\
(2.23)\end{array}$ \\
\hline G8DUMMY & ------- & $\begin{array}{c}0.154 * * \\
(2.18)\end{array}$ & $\begin{array}{c}0.179 * * \\
(2.52)\end{array}$ \\
\hline DEFjt & ------ & ---- & $\begin{array}{c}-0.001 * \\
(-1.91)\end{array}$ \\
\hline $\mathrm{R}^{2}$ & 0.84 & 0.85 & 0.85 \\
\hline $\operatorname{adj} R^{2}$ & 0.82 & 0.83 & 0.83 \\
\hline $\mathrm{F}$ & $48.98 * * *$ & $46.89 * * *$ & $43.46^{* * *}$ \\
\hline
\end{tabular}

Note: Dependent variable: log RPCYpppjt. t-statistics in parentheses. Newey \& West (1987) heteroskedasticity-corrected standard errors and t-statistics.

$* * *(* *) *$ Statistically significant at $1 \%(5 \%) 10 \%$ level.

Of these findings, the result for variable $\mathrm{TF}$ may be of particular relevance to the policy concerns of the O.E.C.D. (2009). In particular, the O.E.C.D. Secretary-General Angel Gurria (OECD, 2009) has recently stressed that "We must ensure that today's policies to manage the [economic] crisis not be the source of tomorrow's problems...Governments must resist protectionism and keep markets open to competition as they seek ways to get their economies 
going again." In other words, the findings in this empirical study confirm that trade freedom is an important source of economic growth and thus should not be abandoned.

\section{References}

Akcay, S. (2006). Corruption and human development, Cato Journal, 25 (1), pp. 25-27.

Barro, R.J. (1997). Determinants of economic growth: a cross-country empirical study, Cambridge, MA, M.I.T. Press.

Brito-Bigott, O., Faria, H.J., Rodriguez, J.M., \& Sanchez, A. (2008). Corruption and complex business rules, Journal of Private Enterprise, 24 (1), pp. 1-15.

Carlson, K.M., \& Spencer, R. W. (1975). Crowding out and its critics, Federal Reserve Bank of St. Louis Review, 60 (12), pp. 1-19.

Cebula, R.J. (1978). An empirical analysis of the crowding out of fiscal policy in the United States and Canada, Kyklos, 31 (3), pp. 424-436.

Cebula, R.J. (1995). The impact of federal government budget deficits on economic growth in the U.S.: an empirical investigation, 1955-1992, International Review of Economics and Finance, 4 (2), pp. 245-252.

De Haan, J., \& Siermann, C.L.J. (1998). Further evidence on the relationship between economic freedom and economic growth, Public Choice, 95 (4), pp. 363-380.

De Haan, J., \& Sturm, J.E. (2000). On the relationship between economic freedom and economic growth, European Journal of Political Economy, 16 (2), pp. 215-241.

Goldsmith, A.A. (1995). Democracy, property rights and economic growth, The Journal of Development Studies. 32 (2), pp. 157-174.

Heckelman, J.C. (2000). Economic freedom and economic growth: a short-run causal relationship, Journal of Applied Economics, 3 (1), pp. 71-91.

Heckelman, J.C., \& Stroup, M.D. (2000). Which economic freedoms contribute to economic growth? Kyklos, 53 (4), pp. 527-544.

Heritage Foundation. (2008). Economic freedom indices: [Online] Available: http://www.heritage.org/Index/Explore.aspx (accessed March 26, 2009)

International Monetary Fund. (2008). Economic growth data: [Online] Available:

http://www.imf.org/external/pubs/ft/weo/2008/02/weodata/weoselser.aspx?c=512\%

(accessed March 25, 2009).

Newey, W.K., \& West, K.D. (1987). A simple positive semi-definite, heteroskedasticity and autocorrelation consistent covariance matrix, Econometrica, 55 (4), pp. 703-708.

O.E.C.D. (2008). Economic data for O.E.C.D. nations: [Online] Available:

http://www.stats.oecd.org/wbos/index.aspx (accessed March 27, 2009) 
O.E.C.D. (2009). Policy brief: Keeping markets open at times of economic crisis, Paris, France: OECD.

World Bank. (2009). Governance matters: [Online] Available:

http://info.worldbank.org/goverance/wgi/mc_countries.asp (accessed March 30, 2009). 